\title{
HISTORYCY WARSZAWSCY W LATACH WOJNY I OKUPACJI (1939-1945)
}

Tragiczne i zarazem pełne heroizmu dzieje historyków warszawskich w okresie II wojny światowej nie doczekały się, jak dotąd, monograficznego opracowania. Tzw. literatura przedmiotu jest w tym wypadku więcej niż skromna. Nekrologi i opracowania, poświęcone poszczególnym historykom, zawierają wprawdzie dłuższe lub krótsze wzmianki na temat ich losów wojennych i okupacyjnych, ale nie dają przecież obrazu całości zjawiska. Nie wszyscy historycy czynni przed 1939 r. wWarszawie doczekali się drukowanego wspomnienia. Z kolei w wielu nekrologach i opracowaniach znajdujemy informacje cząstkowe, niepewne a nawet ewidentnie fałszywe. Szerszy zakres mają dwa opracowania, które zresztą tylko częściowo wiążą się z interesującym nas tu tematem. I tak Aleksander Gieysztor w swej pracy, poświęconej historykom warszawskim w latach 1918-1939¹, podał również nieco informacji dotyczących ich losów późniejszych - wojennych i okupacyjnych. Niestety, dotyczą one wyłącznie profesorów, docentów, adiunktów i asystentów związanych z Instytutem Historycznym Uniwersytetu Warszawskiego. Ogólny obraz polskiego środowiska historycznego w latach wojny i okupacji nakreśliła dwukrotnie Halina Winnicka ${ }^{2}$. Obejmuje on również historyków warszawskich, którzy jednakże, podobnie jak ich koledzy Iwowscy czy krakowscy, nie zostali wyraźnie i konsekwentnie przez autorkę wyodrębnieni.

Temat niniejszego artykułu jest na tyle ważny, obszerny i złożony, iż mógłby (i zapewne powinien) stanowić przedmiot obszernej książki. Nie ulega wątpliwości, iż książka taka wcześniej czy później się ukaże i w istotny sposób wzbogaci naszą wiedzę o dziejach historiografii i inteligencji polskiej $X X$ w. Jej powstanie wymagać jednak będzie podjęcia rozległych prac przygotowawczych, opracowania wielu zagadnień cząstkowych, zestawień i analiz statystycznych. Opracowanie nasze traktujemy więc jako skromny przyczynek do realizacji tego zadania.

Artykuł niniejszy powstał na marginesie badań nad środowiskiem historycznym II Rzeczypospolitej, prowadzonych w latach 1983-1989 w Zakładzie Historii Historiografii i Dydaktyki Historii Uniwersytetu Warszawskiego, przy aktywnym udziale przedstawicieli wielu innych ośrodków naukowych kraju ${ }^{3}$. Zebrano obfity materiał dotyczący także późniejszych losów historyków polskich, który, podobnie jak i pozostałe informacje, został naniesiony na specjalnie w tym celu sporządzone karty dokumentacyjne. Stanowiły one następnie podstawę dla różnych zestawień i analiz statystycznych. Taki też, głównie kwantytatywny charakter mają nasze rozważania poświęcone historykom warszawskim w latach 1939-1945. 
Zanim przejdziemy do zaprezentowania uzyskanych wyników musimy wyjaśnić, kogo uznaliśmy za historyka. Sprawa nie jest wcale tak prosta, jakby to się z pozoru mogło wydawać. Wybraliśmy następującą definicję:

„Historykiem jest każdy, kto prowadzi badania naukowe w dziedzinie historii (nad przeszłościa), zajmuje się w sposób fachowy (umiejętny) edytorstwem źrodeł historycznych i naukową informacją historyczną, upowszechnia w druku wiedzę historyczną lub też uprawia ogólniejszą refleksję nad przeszłością, nauką historyczną i nauczaniem historii".

Przyjęliśmy przy tym następujące założenia:

„1. Badaniami objęci zostaną wszyscy historycy dziejów politycznych, społeczno-gospodarczych, państwa i prawa, wojen i wojskowości, oświaty oraz kultury. W tym ostatnim przypadku chodzi o badaczy zajmujących się ogólnymi problemami rozwoju nauki, życia umysłowego, kultury artystycznej i materialnej itp. Uwzględni się również wszystkich autorów podręczników szkolnych.

2. Spośród historyków Kościoła, reprezentantów nauk pomocniczych, edytorów źródeł i archiwoznawców pominie się jedynie tych, którzy mieli na swym koncie skromny dorobek naukowy lub też podejmowali tematy bardzo wąskie, o nikłym znaczeniu dla badań historycznych i kultury historycznej spoleczeństwa.

3. Większą selekcję przeprowadzi się wśród przedstawicieli dyscyplin wyspecjalizowanych, takich jak: archeologia, historia literatury, historia sztuki, historia teatru, historia filozofii, historia książki, historia muzyki, historia poszczególnych nauk przyrodniczych (np. fizyki, chemii) itp. Uwzględni się jedynie tych archeologów, historyków literatury, sztuki itp., którzy podejmowali - w obrębie swojej specjalności - szerszą problematykę badawczą, byli cytowani przez historyków lub też uczestniczyli w dyskusjach przez nich toczonych.

4. Powyższa zasada dotyczy również przedstawicieli dyscyplin pokrewnych, takich jak: filozofia, ekonomia, prawo, nauki polityczne, socjologia, etnografia, demografia, pedagogika. Zostaną uwzględnieni jedynie ci filozofowie, ekonomiści, prawnicy itp., którzy wnieśli jakiś wkład do badań historycznych, a także refleksji metodologicznej i dydaktycznej w tej dziedzinie.

5. Największej selekcji poddani zostaną historycy-amatorzy, zajmujący się historią regionalną i lokalną, a także bibliografowie historyczni, popularyzatorzy, dydaktycy historii, historiozofowie, publicyści, eseiści i pamiętnikarze. Uwzględni się jedynie postacie najbardziej reprezentatywne dla każdej z tych grup, a także, rzecz jasna, osoby biorące udział w przedsięwzięciach zbiorowych, podejmowanych przez historyków".

Przyjęte założenia mają oczywiście charakter dyskusyjny. Łatwo zauważyć, że choć zerwaliśmy $z$ wąskim rozumieniem historiografii, nie zaakceptowaliśmy również najszerszej wykładni tego pojęcia. Przyjęte rozwiązanie ma charakter kompromisowy i podyktowane zostało w dużej mierze względami praktycznymi (ograniczone środki finansowe przeznaczone na badania).

Interesowali nas jedynie historycy publikujący swoje prace przed $1939 \mathrm{r}$. Jedyny wyjątek uczyniono dla autorów rozpraw doktorskich napisanych i obronionych do września 1939 r., o ile, rzecz jasna, ukazały się one drukiem w okresie późniejszym. 
Przedmiotem naszego zainteresowania są, jak już o tym była mowa, historycy związani z Warszawą i warszawskim środowiskiem historycznym w okresie bezpośrednio poprzedzającym wybuch II wojny światowej. Pomijamy więc tu osoby, które wcześniej ze stolicy wyemigrowały lub też dopiero później (po 1 IX 1939 r.) do niej napłynęły. W okresie okupacji znalazło w Warszawie (lub jej okolicach) schronienie ok. 40 historyków związanych wcześniej z innymi ośrodkami naukowymi kraju. Tytułem przykładu wymienimy tu przybyłych z Poznania Stanisława Bodniaka, Władysława Kowalenko, Kazimierza Chodynickiego i Kazimierza Tymienieckiego. Z Łodzi wyemigrowali do Warszawy m.in. Jadwiga Krasicka, Zygmunt Lorentz i Stanisław Więckowski, ze Lwowa - Łucja Charewiczowa i Piotr Kupczyński, z Krakowa - Józef Feldman. Historycy ci zostali w naszych analizach pominięci, całą uwagę skupiliśmy bowiem na historykach miejscowych, związanych z Warszawą w latach bezpośrednio poprzedzających wybuch wojny światowej.

Warszawa była w latach 1918-1939 najliczniejszym w kraju skupiskiem historyków ${ }^{4}$. Niemal co trzeci historyk polski związany był w tym czasie ze stolicą.

W roku 1939 warszawskie środowisko historyczne skupiało ok. 340 badaczy i popularyzatorów historii. Do momentu przerwania (z powodu braku środków finansowych) prac dokumentacyjnych udało nam się zebrać w miarę kompletne dane dotyczące 276 osób. Tak więc karty dokumentacyjne, stanowiące podstawę dla naszych rozważań, posiada $81,1 \%$ historyków związanych z Warszawą przed wybuchem wojny 1939 r. Zebrany przez nas materiał nie jest więc kompletny, gdyż pomija 64 osoby. W większości przypadków są to historycy młodzi (w 1939 r.!) lub działający na obrzeżach nauki historycznej (amatorzy, popularyzatorzy itp.), z reguhy nie upamiętnieni żadnym tekstem drukowanym, nawet nekrologiem. W wielu przypadkach nie udało się również znaleźć o nich żadnych informacji archiwalnych.

Przedmiotem naszego zainteresowania będzie więc tylko owa grupa 276 historyków posiadających karty dokumentacyjne.

Strukturę demograficzną warszawskiego środowiska historycznego w roku 1939 przedstawia tab. 1. Z podanych w niej danych wynika, iż było ono zdominowane przez mężczyzn, którzy stanowili $90,2 \%$ badanej populacji. Stosunkowo niski był odsetek historyków młodych (43; 15,6\%); historyków w średnim wieku było 119 $(43,1 \%)$, starszych $-114(41,3 \%)$. Stopień doktorski posiadało 16 kobiet i 163 mężczyzn, razem 179 osób $(64,9 \%)$, habilitację zaś 4 kobiety i 83 mężczyzn (łącznie 87 osób, tj. 31,5\% badanej zbiorowości). Większość historyków pracowała (etat, zajęcia zlecone) w szkołach wyższych, innych placówkach naukowych, archiwach i bibliotekach naukowych. Dla wielu źródłem utrzymania była praca w szkole, w licznych w Warszawie urzędach, placówkach wojskowych, instytucjach sądowych i kościelnych, wydawnictwach itp.

Zebrany przez nas materiał dotyczy wielu zagadnień. W opracowaniu niniejszym ograniczymy się do zaprezentowania siedmiu, naszym zdaniem najważniejszych. Postawiliśmy sobie następujące pytania:

1. llu historyków wzięło udział w kampanii wrześniowej 1939 r.? 2. Ilu służyło w polskich formacjach zbrojnych na Zachodzie? 3. Ilu znalazło się w konspiracji i uczestniczyło w zbrojnym ruchu oporu? 4. Ilu podjęło tajne nauczanie i uczestniczyło w innych formach cywilnego ruchu oporu? 5. Ilu aresztowano, internowano 
bądź zesłano do obozów? 6. Ilu zmarło, zostało zamordowanych lub poległo? 7. Ilu kontynuowało, w miarę możliwości, swoją pracę naukową lub pokrewną? Wyniki naszych poszukiwań i obliczeń ujęte są w tab. 2.

W wojnie obronnej 1939 r. uczestniczyło 35 (12,7\%) historyków, głównie, rzecz jasna, z młodszego i średniego pokolenia, m.in. Henryk Bagiński, Jan Ciałowicz, Andrzej Dereń, Aleksander Gieysztor, Andrzej Grodek, Stanisław Groniowski, Witold Hubert, Henryk Jabłoński, Adam Krokiewicz, Adam Lewak, Wacław Lipiński, Kazimierz Michałowski, Tadeusz Mikulski, Adam Moraczewski, Roch Morcinek, Józef Moszczeński, Bronisław Pawłowski, Edward Perkowicz, Stanisław Ploski, Stefan Pomarański, Juliusz Starzyński, Artur Śliwiński, Aleksander Turyn, Henryk Wereszycki, Jan Zachwatowicz i Zdzisław Zmigryder-Konopka. Wielu mężczyzn, na ochotnika, uczestniczyło $w$ obronie Warszawy, nie tylko $z$ bronią $w$ ręku, ale także z lopatą i kilofem, przy kopaniu rowów, budowie barykad itp. Tak było np. w przypadku Józefa Dutkiewicza i Stanisława Herbsta. Inni ratowali dobra kultury przed zniszczeniem, zabezpieczali zbiory biblioteczne, archiwalne itp. W akcji tej wzięło udział co najmniej 50 historyków. Kobiety niosły pomoc medyczną obrońcom Warszawy. I tak $\mathrm{np}$. Wanda Moszczeńska zorganizowała pod kierunkiem prof. Edwarda Lotha opiekę nad rannymi szpitala przeniesionego na teren Uniwersytetu ze zbombardowanego gmachu przy ul. Nowomiejskiej.

Nie brakowało również historyków warszawskich w polskich formacjach zbrojnych na Zachodzie. W sumie doliczyliśmy się ich 8 (2,9\% badanej zbiorowości). Tytułem przykładu wymienimy tu Henryka Bagińskiego, Henryka Jabłońskiego, Edwarda Perkowicza i Romana Piotrowskiego. Do grupy tej można również zaliczyć Zdzisława Obertyńskiego - kapelana wojskowego we Francji (1940), później polskiego kaznodzieję w BBC. Warto przy sposobności zaznaczyć, że były również przypadki służby w Armii Czerwonej (wcielono do niej m.in. Artura Eisenbacha).

Oczywiste jest, że przytłaczająca większość historyków warszawskich pozostała w kraju. Wielu z nich zaangażowało się mniej lub bardziej głęboko w działalność konspiracyjną. Grupa ta liczyła co najmniej 25 osób (9,5\% badanej zbiorowości). Kilkunastu pracowało lub współpracowało z Biurem Informacji i Propagandy SZP - ZWZ - AK. Wymienić tu przede wszystkim należy Aleksandra Gieysztora (szef Wydziału Informacji BIP-u KG AK) i Stanisława Płoskiego (szef Wojskowego Biura Historycznego). Z BIP-em współpracowali: Marceli Handelsman, Stanisław Herbst, Ludwik Kolankowski, Stefan Kieniewicz, Witold Kula, Kazimierz Kumaniecki, Marian Małowist, Tadeusz Manteuffel, Janusz Pajewski, Adam Próchnik, Ludwik Widerszal i in. Szefem BIP-u Okręgu AK Węgry był Stefan Pomarański. Ponadto należeli do AK lub z nią wspólpracowali: Jan Czuj, Józef Dutkiewicz, Gustaw Kaleński, Czesław Leśniewski, Jerzy Manteuffel, Michał Walicki i in. Działalność konspiracyjną w mniejszym lub większym zakresie prowadzili również Kazimierz Konarski, Wacław Lipiński, Marian Małowist, Adam Moraczewski, Wanda Moszczeńska, Kazimierz Zakrzewski $i$ in. W sumie, jak wynika z naszych obliczeń, z konspiracją polityczną i wojskową lat 1939-1945 związany był co dziesiąty historyk warszawski.

Znacznie więcej, bo 90 osób (32,2\%), uczestniczyło w różnych formach cywilnego ruchu oporu. Główną z nich było tajne nauczanie, które prowadziło 87 
historyków. Na różnych kierunkach tajnego Uniwersytetu Warszawskiego przedmioty historyczne (i pokrewne) wykładali m.in. Włodzimierz Antoniewicz, Stanisław Borowski, Wacław Borowy, Marceli Handelsman, Jadwiga Karwasińska, Stanisław Kętrzyński, Stefan M. Kuczyński, Kazimierz Kumaniecki, Zygmunt Lorentz, Zygmunt Łempicki, Bogdan Nawroczyński, Hanna Pohoska, Józef Rafacz, Roman Rybarski, Władysław Tatarkiewicz, Władysław Tomkiewicz, Michał Walicki, Ludwik Widerszal, Janusz Woliński i Jan Zachwatowicz. Organizatorem i zarazem główną postacią studium historycznego na tajnym Uniwersytecie Warszawskim był Tadeusz Manteuffe ${ }^{5}$. Poza strukturami tajnego UW działało seminarium metodologiczne Wandy Moszczeńskiej, skupiające niektórych dawnych jej sluchaczy na UW.

Niektórzy spośród wyżej wymienionych prowadzili również zajęcia na tajnym Uniwersytecie Ziem Zachodnich. Z uczelnią tą związany był także m. in. Mieczysław Żywczyński. W tajnej Wolnej Wszechnicy Polskiej wykładali m.in. Natalia Gąsiorowska, Stanisław Herbst i Helena Radlińska, zaś w tajnej Szkole Głównej Gospodarstwa Wiejskiego - Antoni Zabko-Potopowicz. Historycy warszawscy prowadzili również zajęcia uniwersyteckie w Kielcach, Częstochowie i Lublinie.

Tajnym nauczaniem na poziomie szkoły średniej i powszechnej zajmowali się m.in. Stanisław Arnold, Oskar Bartel, Cezary Berezowski, Iza Bieżuńska, Józef Dutkiewicz, Marian Janelli, Julia Kisielewska, Marian Kniat, Jadwiga Lechicka, Adam Lewak, Witold Łukaszewicz, Marian Małowist, Władysława Martynowiczówna, Anna Minkowska, Henryk Mościcki, Halina Mrozowska, Adam Próchnik, Marian Henryk Serejski i Andrzej Zand.

Udział w wojnie obronnej 1939 r., w konspiracji i tajnym nauczaniu, a także w powstaniu warszawskim $1944 \mathrm{r}$. wielu przypłaciło internowaniem bądź aresztowaniem, a nierzadko także zesłaniem na przymusowe roboty, osadzeniem w obozie jenieckim lub koncentracyjnym. Dotknęło to, jak zdołaliśmy ustalić 78 osób, a więc 27,9\% badanych przez nas historyków. Tytułem przykładu wymienimy tu: Włodzimierza Antoniewicza, Stanisława Arnoida, Kazimierza Budzyka, Edmunda Bursche, Jana Bystronia, Edwarda Chwalewika, Jana Ciałowicza, Natalię Gąsiorowską, Bronisława Gembarzewskiego, Aleksandra Gieysztora, Olgierda Górkę, Marcelego Handelsmana, Stanislawa Herbsta, Henryka Hilchena, Wandę Kiedrzyńską, Stefana Kieniewicza, Emila Kipę, Zofię Krausównę, Zofię Krzemicką, Witolda Kulę, Jadwigę Lechicką, Adama Lewaka, Józefa Lewickiego, Waclawa Lipińskiego, Witolda Łukaszewicza, Kazimierza Michałowskiego, Rocha Morcinka, Zdzisława Obertyńskiego, Henryka Paszkiewicza, Bronisława Pawłowskiego, Stanisława Płoskiego, Stefana Pomarańskiego, Rudolfa Ranoszka, Ignacego Schipera, Juliusza Starzyńskiego, Czesława Strzeszewskiego, Henryka Wereszyckiego, Jana A. Wildera, Kazimierza Zakrzewskiego i Adama Zieleńczyka. Do Oświęcimia zostali wysłani m.in. Jan Cynarski-Krzeslawski, Adam Englert, Karol Frycz, Stanisław Kętrzyński, Zygmunt Łempicki, Adam Moraczewski, Wanda Moszczeńska, Irena Pannenkowa, Józef Putek, Roman Rybarski, Marian H. Serejski, Józef Siemieński i Andrzej Zand. W getcie warszawskim osadzono Majera Bałabana, Izę Bieżuńską, Mariana Małowista, Emanuela Ringelbluma i in. 
Kilkuosobowa grupa historyków warszawskich znalazła się po wrześniu 1939 r. na terenach zajętych przez Armię Czerwoną. Jedną z ofiar radzieckich prześladowań był Adam Benisz.

W tym kontekście chcemy zasygnalizować straty osobowe warszawskiego środowiska historycznego w okresie wojny i okupacji. Spośród badanych przez nas 276 historyków nie przeżyło wojny $76(27,5 \%)$.

Stosunkowo niewielu umarło śmiercią naturalną, przytłaczająca większość zginęła z rąk hitlerowskiego najeźdźcy i okupanta: na polach bitew, w więzieniach i obozach koncentracyjnych, w wyniku masowych rozstrzeliwań na ulicach Warszawy itp. Na liście strat osobowych warszawskiego środowiska historycznego znajduja się m.in. następujące nazwiska: Roman Archutowski, Majer Bałaban, Zygmunt Batowski, Eugeniusz Boss, Edmund Bursche, Jadwiga ChrząszczewskaSuchodolska, Jan Cynarski-Krzesławski, Stefan Dziewulski, Karol Frycz, Bronisław Gembarzewski, Franciszek Giedroyć, Stanisław Groniowski, Hipolit Grynwaser, Samuel Hirszchorn, Marceli Handelsman, Gustaw Kaleński, Marian Kniat, Michał Kreczmar, Stanisław Kryczyński, Zofia Krzemicka, Józef Lewicki, Zygmunt Łempicki, Maksymilian Meloch, Michał Mendys, Adam Moraczewski, Mieczysław Niedziałkowski, Aleksander Patkowski, Kazimierz Piekarski, Stefan Pomarański, Adam Próchnik, Józef Rafacz, Emanuel Ringelblum, Lucjan Russjan, Roman Rybarski, Ignacy Schiper, Józef Siemieński, Oskar Sosnowski, Kazimierz Wachowski, Ludwik Widerszal, Kazimierz Zakrzewski, Andrzej Zand, Adam Zieleńczyk, Tadeusz Zieliński. Spośród historyków, którzy znaleźli się na terenach zajętych przez Armię Czerwoną i w ZSRR wojny nie przeżyli: Stanisław Cywiński, Mojżesz Schorr, ks. Władysław Nekrasz i Zdzisław Zmigryder-Konopka.

Straty osobowe warszawskiego środowiska historycznego w latach wojny $i$ okupacji były duże, obejmowały więcej niż czwartą część jego stanu z roku 1939. Wielu, w wyniku cierpień wojennych, zmarło tuż po 1945 r. lub odniosło poważny uszczerbek na zdrowiu, który uniemożliwił im normalne życie i pracę naukową.

Wojna rozproszyła znaczną część historyków warszawskich. Tytułem przykładu zwrócimy tu uwagę na dalsze losy profesorów studium historycznego Uniwersytetu. W chwili wybuchu wojny skupiało ono 9 profesorów: 7 tzw. czynnych (zwyczajnych i nadzwyczajnych) oraz 2 tytularnych ${ }^{6} .3$ z nich zginęlo w dramatycznych okolicznościach (M. Bałaban, M. Handelsman, K. Zakrzewski), 4 innych rozproszyła wojna. 3 z nich znalazło się za granicą i tam pozostało (O. Halecki, M. Korduba i T. Wałek-Czernecki), 1 zaś przenióst się do Krakowa (H. Mościcki). $Z 9$ dawnych profesorów pozostało w Warszawie tylko 2: S. Arnold iS. Kętrzyński. Drugi z nich z powodu złego stanu zdrowia wykładów już nie podjął, ograniczył się do prowadzenia - przez pewien czas - seminarium dla swoich uczniów. S. Arnold był tak mocno zaabsorbowany zajęciami pozauniwersyteckimi, iż niewiele czasu poświęcał zarówno pracy naukowej, jak dydaktycznej. Studium historyczne wznowiło po wojnie swoją działalność $w$ gruntownie zmienionym składzie personalnym. Także większość dawnych docentów rozproszyła się po kraju i świecie (niektórzy zginęli); ich miejsca zajmowali stopniowo nowi, często bardzo młodzi ${ }^{7}$.

Powróćmy do głównego wątku naszych rozważań. Szczupłe ramy artykułu uniemożliwiają pełniejsze przedstawienie aktywności twórczej historyków warsza- 
wskich w latach wojny i okupacji. Mimo grozy sytuacji, ciężkich warunków materialnych, nieustannego zagrożenia życia, niedostępności potrzebnych materiałów itp. wielu historyków w mniejszym lub większym zakresie kontynuowało pracę naukową (lub pokrewna) przerwaną wybuchem wojny. Dało się to stwierdzić w 106 przypadkach ( $38,4 \%$ badanej populacji). Oto kilkanaście przykładów, wydobytych z kart dokumentacyjnych. Przedstawimy je w porządku alfabetycznym.

Natalia Gąsiorowska podjęła trud opracowania dwu podręczników akademickich: „Historii gospodarczo-społecznej Polski” i „Historii gospodarczo-społecznej powszechnej". Pierwszy liczył 1135, drugi 1469 stron maszynopisu. Obie prace przetrwały szczęśliwie wojnę i okupację, jednakże nie zostały później opublikowa$n e^{8}$. Nie ukazały się również drukiem N. Gąsiorowskiej „Wskazówki metodologiczne do badań historycznych", pisane na zlecenie Komisji Podręczników Akademickich, działającej przy Wydziale Nauki i Szkolnictwa Wyższego tajnego Departamentu Oświaty i Kultury?.

Sędziwy Bronisław Gembarzewski po zwolnieniu z więzienia wykańczał swe monumentalne dzieło o uzbrojeniu i umundurowaniu wojska polskiego ${ }^{10}$. Praca ta - „Żołnierz polski. Ubiór, uzbrojenie i oporządzenie od wieku XI do roku 1960" (!) ukazała się w 4 tomach w latach 1960-1966. Sam Gembarzewski nie przeżył okupacji, zmarł w grudniu $1941 \mathrm{r}$.

Reprezentujący najmłodsze wówczas pokolenie Aleksander Gieysztor w okresie wojny pracował nad swoją rozprawą doktorską ,Ze studiów nad genezą wypraw krzyżowych. Encyklika Sergiusza IV (1009-1012)". Promocja odbyła się tuż po wojnie, dysertacja zaś została opublikowana w 1948 r. A. Gieysztor opracował również skrypt „Encyklopedia nauk pomocniczych", powielony tajnie w 1943 r., (3 zmienione wyd., przygotowane przy współpracy S. Herbsta ukazało się w 1948 r.) ${ }^{11}$.

Przykładem pracowitości mógł świecić młodzieży niekwestionowany przywódca warszawskiego środowiska historycznego - Marceli Handelsman. Mieszkając w Milanówku, w którym schronił się w obawie przed represjami niemieckimi, pracowal nad ostatnią swoją monografią, nad wielkim, trzytomowym dziejem poświęconym Adamowi Czartoryskiemu. Autor, odcięty od bibliotek i archiwów, opieral się na zdekompletowanych w czasie oblężenia Warszawy wlasnych notatkach i książkach, które mu uczniowie ukradkiem dostarczali. Dzieło to, przygotowane do druku przez S. Kieniewicza ukazało się w latach $1948-1950^{12}$. Nie była to jedyna praca M. Handelsmana napisana w okresie wojny, spod jego pióra wyszedł także wówczas m.in. ciekawy, popularny zarys historii Polski, dotychczas nieopublikowany.

Stanisław Herbst w okresie okupacji pracował nad swoją rozprawą habilitacyjną „Ulica Marszałkowska”. Praca ta, referowana na jednym z tajnych posiedzeń Towarzystwa Urbanistów Polskich, ukazala się drukiem w roku $1949^{13}$.

Dość intensywnie pracował również naukowo prezes działającego potajemnie w Warszawie Towarzystwa Miłośników Histonii-Stanisław Kętrzyński, który podją prace nad "Studiami XI wieku". Znaczna część z nich została ukończona jeszcze przed aresztowaniem w listopadzie 1943 r., a następnie zesłaniem do Oświęcimia ${ }^{14}$. Niektóre z tych studiów ukazały się w pierwszych latach powojennych, całość wydał A. Gieysztor w 1961 r. w zbiorze prac S. Kętrzyńskiego „Polska X-XI wieku”. Niestety, zniszczeniu 
uległy spisywane w okresie wojny wspomnienia S. Kętrzyńskiego, zdaniem A. Gieysztora „świetny dokument własnego życia i środowiska"15.

Systematycznie i wydajnie, jak na ówczesne warunki, pracował Emil Kipa. W roku 1942 ukończyl on obszerną monografię sprawy polskiej w 1809 r. Równocześnie przygotowat do druku VI tom "Korespondencji Ks. Józefa". Miała to być korespondencja Józefa Poniatowskiego z Dietrichsteinem. W czasie okupacji E. Kipa pracował również nad drugim, poszerzonym wydaniem monografii o Fryderyku Gentzu. Niemal gotowe były również powstałe wówczas obszerne, dwutomowe „Dzieje wolnomularstwa polskiego". Wszystko to przepadło po powstaniu warszawskim, wraz z wypisami archiwalnymi, notatkami, książkami itp. Tylko niektóre prace udało się częściowo odtworzyć, tak powstała m.in. rozprawa "Austria a sprawa polska w 1809 r." (1952) ${ }^{16}$.

Stefan Kjeniewicz w okresie okupacji pracował nad biografią Michała Bobrzyńskiego, historyka i namiestnika Galicji. Maszynopis tej książki uległ zniszczeniu w czasie powstania warszawskiego. Niejako na marginesie tej pracy powstała później rozprawa S. Kieniewicza o „Dziejach Polski w zarysie M. Bobrzyńskiego” (1948) ${ }^{17}$.

Stanisław Kryczyński w okresie wojny pracował nad swą ostatnią rozprawą "Kronika wojenna Tatarów litewskich", którą po latach (w roku 1984) wydał Jan Tyszkiewicz $^{18}$. Autor zmarl w listopadzie $1941 \mathrm{r}$.

Młodszy od Kryczyńskiego o 5 lat Witold Kula napisał w latach 1941-1944 pierwszą wersję swej fundamentalnej pracy "Problemy i metody historii gospodarczej". Dzieło to po dwukrotnych przeróbkach ukazało się drukiem w $1963 \mathrm{r}$. ${ }^{\text {ig }}$

Intensywnie, jak na ówczesne warunki, pracował naukowo historyk sztuki Zygmunt Lorentz, który w latach 1940-1943 napisal swoją prace habilitacyjną "Natolin", ogłoszoną drukiem w 1948 r. Habilitacja została przeprowadzona jeszcze w okresie wojny, bodajże w $1943 r{ }^{20}$

Tadeusz Manteuffel napisat w okresie okupacji studium „Polska w okresie prawa książęcego 963-1194”, wydane w 1976 r. przez Stanisława Trawkowskiego (w zbiorze prac T. Manteuffla "Historyk wobec historii"). W okresie okupacji narodziło się też opublikowane w 1947 r. zwarte przedstawienie historii średniowiecznej, z którego z czasem wyłonił się uniwersytecki podręcznik tego okresu dziejów ${ }^{21}$.

Nowożytnik Janusz Pajewski napisał w okresie wojny dwa podręczniki: „Historię Polski 1795-1864" i "Historę Polski 1864-1918" oraz monografię o Zygmuncie Auguście. Prace te uległy zniszczeniu w czasie powstania warszawskiego ${ }^{22}$.

Nie zaniechał pracy naukowej Adam Próchnik. W latach 1940-1942, na podstawie wcześniej zebranego materiału, przystapił on do opracowania szeroko zakrojonego studium poświęconego rewolucji francuskiej. Praca ta, niedokończona, została po latach (w 1958 r.) wydana przez Bogusława Leśnodorskiego pt. "Stronnictwa polityczne Wielkiej Rewolucji Francuskiej" (ponad 540 stron druku). W okresie okupacji Próchnik napisał także zarys dziejów ruchu ludowego w Polsce, którego ocalały fragment ogłosili w „Najnowszych Dziejach Polski” Cz. Madajczyk i J. Żarnowski ${ }^{23}$.

Pracą badawczą zajmowali się także historycy żydowscy osadzeni w getcie warszawskim $^{24}$. Tytułem przykładu zwrócimy tu uwagę na działalność Emanuela Ringelbluma. Był on inicjatorem i organizatorem podziemnego Archiwum Getta. 
Bylo ono początkowo pomyślane jako centrum dokumentacji, z czasem stało się ważnym ośrodkiem badawczym. Pisane na gorąco notatki, szkice i eseje Ringelbluma zostały po wojnie uporządkowane chronologicznie i w ten sposób powstała jego „Kronika getta warszawskiego 1939-1943”; polskie jej wydanie ukazało się w 1983 r. Ringelblum jest także autorem obszernego eseju „Stosunki polsko-żydowskie w czasie drugiej wojny światowej", który po raz pierwszy został opublikowany w „Biuletynie Żydowskiego Instytutu Historycznego" w latach 1958-1959. Autor został rozstrzelany na Pawiaku przez Gestapo w marcu 1944 r. ${ }^{25}$

Nie załamywał rąk i Władysław Tatarkiewicz, filozof i historyk sztuki. W czasie okupacji napisał m.in. III tom swej „Historii filozofii”. Rękopis tej pracy spłonał wraz z domem autora w okresie powstania warszawskiego. Po wojnie została ona mozolnie odtworzona i - po uzupełnieniach - opublikowana w roku $1950^{26}$.

Ludwik Widerszal kontynuował swoje studia nad stosunkami międzynarodowymi XIX w. W okresie okupacji napisał dwie prace: „Stosunki polsko-angielskie 1831-1854" oraz „Rosja - Polska”; pierwsza z nich spłonęta w czasie powstania warszawskiego, druga zaginęła w nieznanych bliżej okolicznościach. Także i ich autor nie przeżył wojny, w czerwcu 1944 r. został zamordowany przez bojówkę endeckoenerowską, rzekomo za sprzyjanie komunizmowi ${ }^{27}$.

I ostatni przykład. We wrześniu 1939 r., w czasie oblężenia Warszawy, nowożytnikowi Januszowi Wolińskiemu spłonął wraz z mieszkaniem rękopis gotowej do druku pracy „Od Chocimia do Żórawna”. W okresie okupacji autor próbował ją na powrót odtworzyć, ale i tym razem los mu nie sprzyjał, w czasie powstania warszawskiego stracił następne mieszkanie wraz ze wszystkimi swoimi rękopisami i notatkami $^{28}$.

Kilkudziesięciu historyków warszawskich aktywnie uczestniczyło w ratowaniu zbiorów rękopiśmiennych, bibliotecznych i muzealnych. Opracowywano rękopisy, sporządzano inwentarze, chowano cenniejsze obiekty przed okiem niemieckim. W pracy tej, dość szeroko opisanej w publikacjach zbiorowych: „Walka o oświatę, naukę i kulturę w latach okupacji 1939-1944" (1967), „Walka o dobra kultury. Warszawa 1939-1945" (2 t., 1970), "Straty archiwów i bibliotek warszawskich w zakresie rękopiśmiennych źródeł historycznych" (3 t., 1955-1957) i in. uczestniczyto z górą 50 osób.

Na zakończenie tych pobieżnych z konieczności uwag chcemy jeszcze wspomnieć o historykach, którzy wojnę spędzili poza krajem. Było ich w sumie, łącznie z tymi, którzy dostali się do obozów jenieckich, ok. 30. I tak np. Kazimierz Michałowski po kampanii wrześniowej znalazł się w oflagu w Woldenbergu, w którym przebywał do końca wojny. Tu też dla swoich współtowarzyszy niedoli prowadzł m.in. wykłady z historii sztuki starożytnej.

Tadeusza Wałka-Czerneckiego wypadki wojenne rzuciły na tułaczkę do Francji, Egiptu, Republiki Południowej Afryki i Anglii. Pracując w Instytucie Francuskim w Kairze prowadził badania nad stosunkami ludnościowymi w Egipcie w okresie saickim, których wyniki opublikował w 1940 r. w biuletynie Instytutu. Później prowadził wykłady z historii starożytnej w Johannesburgu ${ }^{29}$. Działalność naukową na obczyźnie prowadzili również m.in. Oskar Halecki i - w mniejszym zakresie Jan Kucharzewski. 
Wybuch wojny zastał Haleckiego w Szwajcarii, skąd udał się do Francji, gdzie zorganizował Polski Uniwersytet Emigracyjny w Paryżu, później wyjechał do Stanów Zjednoczonych. Tu zorganizował Polski Instytut Naukowy w Ameryce, którego od 1942 r. był dyrektorem. W 1944 r. Halecki objął katedrę historii Europy wschodniej na Uniwer sytecie Fordham w Nowym Jorku. Publikował sporo, m.in. w 1942 r. wydał w języku angielskim zarys dziejów Polski ${ }^{30}$.

Jan Kucharzewski pierwszych siedem miesięcy wojny przeżył w okupowanym kraju. W kwietniu 1940 r. przedostał się do Włoch, później krótko przebywał we Francji i Portugalii, skąd wyjechał do Stanów Zjednoczonych. Tu zbierał materiały do projektowanej książki, która miała stanowić przegląd polityki światowej w latach 1919-1939. Zamiaru tego nie wykonał, opracowat natomiast, jeszcze przed zakończeniem wojny, skrót swego dzieła „Od białego caratu do czerwonego”, który ukazał się drukiem w Nowym Jorku w 1948 r. Przez kilka lat był prezesem Polskiego Instytutu Naukowego w Ameryce ${ }^{31}$.

Wszyscy trzej wymienieni ostatnio (T. Walek-Czernecki, O. Halecki, J. Kucharzewski) nie powrócili już do Warszawy, na emigracji pozostali również m.in. dwaj związani z O. Haleckim przedwojenni docenci Uniwersytetu Warszawskiego: Henryk Paszkiewicz i Józef Jasnowski.

Lata 1939-1945 stanowią piękna, ale zarazem i bardzo tragiczną kartę w dziejach warszawskiego środowiska historycznego. Wyszło ono z wojny zdziesiątkowane i poważnie osłabione. Zniszczeniu uległa m.in. większość zbiorowych i indywidualnych warsztatów pracy. Pomimo tych i innych strat nie zaczynano w 1945 r. wszystkiego od początku, było bowiem do czego nawiązać i na czym się oprzeć. Ostała się spora grupa ludzi zahartowanych przez wojnę, zdolnych do wzięcia na swoje barki trudu odbudowy. To był największy kapitał, którym w latach powojennych dysponowało warszawskie środowisko historyczne.

\section{Przypisy}

${ }^{1}$ Por. A. Gieysztor, Środowisko historyczne Warszawy w okresie międzywojennym [W:] Nauka i szkolnictwo wyższe w Warszawie, Warszawa 1987, s. 88-106.

${ }^{2}$ Por. H. Winnicka, Środowisko historyków w latach wojny i okupacji. „Przegląd Humanistyczny” 1975, nr 8, s. 75-89; Tejże, Historycy polscy w latach wojny i okupacji 1939-1945 (Zarys problematyki) W:] Środowiska historyczne II Rzeczypospolitej. Cz. II. Materialy konferencji naukowych w Cedzynie i Białymstoku w 1986 i 1987 pod red. J. Maternickiego, Warszawa 1987, s. 412-437.

${ }^{3}$ Por. J. Maternicki, Polskie środowisko historyczne w latach 1918-1939. Założenia metodologiczne badań, ich organizacja i dotychczasowe wyniki. „Kwartalnik Historyczny", R. 93: 1986, nr 1, s. 165-185. Rezultatem prac badawczych Zespołu "Polskie środowisko historyczne 1918-1939” jest m.in. pięć tomów studiów "Środowiska historyczne II Rzeczypospolitej", wydanych pod red. J. Maternickiego w latach 1986-1990.

${ }^{4}$ Por. J. Maternicki, Infrastruktura warszawskiego środowiska historycznego 1918-1939. „Przegląd Humanistyczny" 1990, nr 5-6, s. 17-39; Tenże, Obraz statystyczny warszawskiego środowiska historycznego 1918-1939. Cz. I-II. „Przegląd Humanistyczny” 1990, nr 7, s. 41-64; nr 8-9, s. 113-125; Tenże, Historycy warszawscy w latach 1918-1939 [W:] Środowiska historyczne II Rzeczypospolitej. Cz. IV. Materialy konferencji naukowej... pod red. J. Maternickiego, Warszawa 1990, s. 98-200; Tenże, Elita warszawskiego środowiska historycznego 1918-1939 [W:] Środowiska historyczne II Rzeczypospolitej. Cz. V, Warszawa 1990, 5. 36-90; Tenże, Geografia historiograficzna II Rzeczypospolitej. "Przegląd Humanistyczny" 1990, nr 2, s. 11-45. Por. także A.F. Grabski, Miejsce ośrodka warszawskiego w historiografii polskiej międzywojennego dwudziestolecia [W:] Tegoż, Orientacje polskiej myśli historycz- 
nej, Warszawa 1972, s. 341-365; J. Maternicki, E. Cesarz, Zainteresowania twórcze historyków warszawskich w latach 1918-1939. „Przegląd Humanistyczny" 1991, nr 1 (w druku).

${ }^{5}$ Pomijamy tu wykładowców nie związanych wcześniej (w 1939 r.) ze środowiskiem warszawskim. Wymienić tu należy przybylą ze Lwowa docent Łucję Charewiczową, doc. WWP w Łodzi - Stanisława Więckowskiego, profesora UJ - Józefa Feldmana i profesora UP - Kazimierza Tymienieckiego. O dzialalności studium historycznego na tajnym Uniwersytecie Warszawskim informuja m.in. wspomnienia T. Manteuffla, J. Karwasińskiej i K. Dunin-Wasowicza, opublikowane w wydawnictwie "Z dziejów podziemnego Uniwersytetu Warszawskiego", Warszawa 1961, s. 207-257. Por. także K. Dunin-Wasowicz, Tadeusz Manteuffel jako organizator tajnego nauczania [W:] Polska w świecie, Warszawa 1972, s. 395-402.

${ }^{6}$ Por. Sklad Uniwersytetu i Spis wykladów na rok akademicki 1938-1939, Warszawa 1938, 5. 23 i n.; A. Gieysztor, Środowisko historyczne Warszawy..., s. 102 i n.

7 Por. T. Manteuffla "Kronikę odbudowy Instytutu Historycznego", ogłoszoną w 1966 r. w "Rocznikach Uniwersytetu Warszawskiego"; Tegoż, Zapiski do wspomnień [W:] Tenże, Historyk wobec historii, Warszawa 1976, s. 340 i n. Por. także wypowiedź A. Gieysztora w ankiecie "Kwartalnika Historycznego": "Trzydzieści pięć lat Polski Ludowej". "Kwartalnik Historyczny" R. 86: 1979, nr 3, s. 623 i n.

${ }^{8}$ Por. Ż. Kormanowa, Ludzie i życie, Warszawa 1982, s, 294-295.

${ }^{9}$ Por. M. Walczak, Szkolnictwo wyższe i nauka polska w latach wojny i okupacji 1939-1945, Wrocław 1979 , s. 120.

${ }^{10}$ Por. Z. Stefańska, Bronisław Gembarzewski - muzeolog. „Kronika Warszawy" 1981, nr 2, s. 18-19.

${ }^{11}$ Por. Aleksander Gieysztor. Doctor honoris causa Universitatis Studiorum Mickiezianae Posnaniensis, Poznań 1990, s. 7.

12 Por. T. Manteuffel, Rola Marcelego Handelsmana w życiu naukowym Warszawy. „Przegląd Humanistyczny" T. 50: 1959, nr 1, s, 10-11.

13 Por. A. Zahorski, Życie i twórczość Stanislawa Herbsta [W:] S. Herbst, Potrzeba historii czyli o polskim stylu życia, T. I, Warszawa 1978, s. 22.

${ }^{14}$ Por. A. Gieysztor, Posłowie [W:] S. Kętrzyński, Polska X-XI wieku, Warszawa 1961, s. 705 i n.

15 Por. A. Gieysztor, Stanisław Kętrzyński (1876-1950) [W:] Historycy warszawscy ostatnich dwóch stuleci, Warszawa 1986, s. 226.

${ }^{16}$ Por. J. Łojek, Życie i działalność naukowa Emila Kipy [W:] E. Kipa, Studia i szkice historyczne, Warszawa 1959, s. XIII-XV.

17 Por. S. Kieniewicz, Z rozmyślań dziejopisa czasów porozbiorowych. „Kwartalnik Historii Nauki i Techniki" R. 25: 1980, nr 2, s. 251.

${ }^{18}$ Por. J. Tyszkiewicz, Stanislaw Kryczyríski i jego „Kronika wojenna Tatarów Litewskich”. „Przegląd Humanistyczny" 1984, nr 2, s. 120 in.

${ }^{19}$ Por. W. Kula, Problemy i metody historii gospodarczej, Warszawa 1963, s. 8.

${ }^{20}$ Por. S. Lorentz, Zapiski do autobiografii. „Kwartalnik Historii Nauki i Techniki” R. 24: 1979, nr 4, s. 743 i n.

${ }^{21}$ Por. S. Trawkowski, Posłowie [W:] T. Manteuffel, Historyk wobec historii, Warszawa 1976, s. 414.

22 Por. Janusz Pajewski, doktor honoris causa UAM, Warszawa 1979, s. 6-7.

23 Por. S.S. Nicieja, Adam Próchnik, Warszawa 1986, s. 370-372.

24 Por, A. Eisenbach, Badania naukowe w getcie warszawskim. „Bleter far geszichte" T. 1: 1948, nr 1, s. 55-113; nr 2, s. 69-84; T. 4: 1951, nr 1, s. 36-53. Por. ponadto „Biuletyn Żydowskiego Instytutu Historycznego" 1951, nr 1, s. 27-48.

${ }^{25}$ Por. A. Eisenbach, Wstęp [W:] E. Ringelblum, Stosunki polsko-żydowskie w czasie drugiej wojny światowej, Warszawa 1988, s. 21 i n. 
${ }^{26}$ Por. W. Tatarkiewicz, Zapiski do autobiografii. „Kwartalnik Historii Nauki i Techniki” R. 21: 1975, nr 2, s. $230 \mathrm{in}$.

27 Por. A. Zahorski, Wspomnienie o Ludwiku Widerszalu (1909-1944). „Kronika Warszawy" 1980, nr 2, 5. 117-121.

${ }^{28}$ Por. Z. Wójcik, Profesor Janusz Woliński (1894-1970). „Kronika Warszawy” 1980, nr 2, s. 127.

29 Por. W. Lengauer, Tadeusiz Wałek-Czernecki (1889-1949) [W:] W kręgu wielkich humanistów. Kultura antyczna w Uniwersytecie Warszawskim po I wojnie światowej, pod red. Izy Bieżuńskiej-Małowist, Warszawa 1991, 5. 140-141.

30 J. Pajewski, Oskar Halecki 26 V 1891-17 IX 1973. "Kwartalnik Historyczny" R. 82: 1975, nr 4, s. 915-916.

${ }^{31}$ Por. J. Maternicki, Kucharzewski Jan (1876-1952), historyk, prawnik, publicysta i polityk [W:] Polski słownik biograficzny, t. 16, 1971, s. 60-61.

Tabela 1. Historycy warszawscy w roku 1939 według płci i wieku

\begin{tabular}{|c|c|c|c|c|c|c|c|c|c|c|c|}
\hline \multicolumn{9}{|c|}{ Grupa wiekowa } & \multirow{2}{*}{\multicolumn{2}{|c|}{ Ogólem }} & \multirow{3}{*}{ Fazem } \\
\hline \multicolumn{3}{|c|}{ do 35 lat } & \multicolumn{3}{|c|}{$36-50$ lat } & \multicolumn{3}{|c|}{ powyżej 50 lat } & & & \\
\hline $\begin{array}{c}\text { kobie- } \\
\text { ty }\end{array}$ & $\begin{array}{l}\text { męż- } \\
\text { czyźni }\end{array}$ & razem & $\begin{array}{l}\text { ko- } \\
\text { biety }\end{array}$ & $\begin{array}{l}\text { męż- } \\
\text { czyźni }\end{array}$ & razem & $\begin{array}{c}\text { kobie- } \\
\text { ty }\end{array}$ & $\begin{array}{l}\text { męż- } \\
\text { czyźni }\end{array}$ & razem & $\begin{array}{l}\text { ko- } \\
\text { biety }\end{array}$ & $\begin{array}{l}\text { męż- } \\
\text { czyźni }\end{array}$ & \\
\hline 3 & 40 & 43 & 19 & 100 & 119 & 5 & 109 & 114 & 27 & 249 & 276 \\
\hline $1,1 \%$ & $14,5 \%$ & $15,6 \%$ & $6,9 \%$ & $36,2 \%$ & $43,1 \%$ & $1,8 \%$ & $39,5 \%$ & $41,3 \%$ & $9,8 \%$ & $90,2 \%$ & $100,0 \%$ \\
\hline
\end{tabular}

Tabela 2. Historycy warszawscy w latach 1918-1939

\begin{tabular}{|r|l|r|}
\hline Lp. & Losy w okresie wojny i okupacji & Liczba historyków \\
\hline 1. & Udzial w wojnie obronnej $1939 \mathrm{r}$. & $35 \quad(12,7 \%)$ \\
2. & Udzial w walkach na frontach zachodnich & $(2,9 \%)$ \\
3. & Udzial w konspiracji politycznej i zbrojnym ruchu & $25 \quad(9,5 \%)$ \\
& oporu w okupowanym kraju & $90 \quad(32,2 \%)$ \\
5. & Udzial w cywilnym ruchu oporu & $78 \quad(27,9 \%)$ \\
5. & Aresztowani, internowani i zesłani do obozów & $76 \quad(27,5 \%)$ \\
7. & Zmarli, zamordowani i polegli & $106 \quad(38,4 \%)$ \\
\hline
\end{tabular}

Ogółem 276 osób $(100,0 \%)$ 